\title{
Signal Transduction and Smooth Muscle
}

Edited by Mohamed Trebak Scott Earley

ISBN: 978-1-4987-7422-2 (hbk)

ISBN: 978-1-315-15458-9 (ebk)

First published 2019

\section{Chapter 9}

Mitochondria Structure and Position in the Local Control of Calcium Signals in Smooth Muscle Cells

John G. McCarron, Christopher Saunter, Calum Wilson,

John M. Girkin, and Susan Chalmers

(CC BY-NC-ND 4.0)

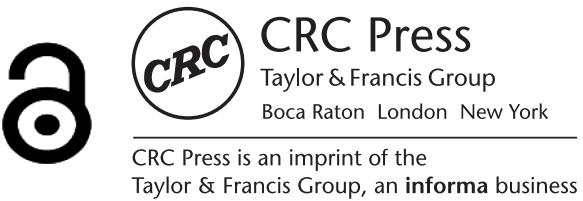





\title{
9 Mitochondria Structure and Position in the Local Control of Calcium Signals in Smooth Muscle Cells
}

\author{
John G. McCarron, Christopher Saunter, \\ Calum Wilson, John M. Girkin, and Susan Chalmers
}

\section{CONTENTS}

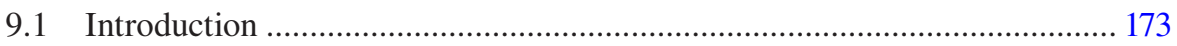

9.2 Role of Mitochondria in $\mathrm{Ca}^{2+}$ Signaling .................................................... 176

9.3 Mitochondria Structure in Native Cells........................................................ 181

9.4 Mitochondrial Position and Signaling via Voltage-Dependent

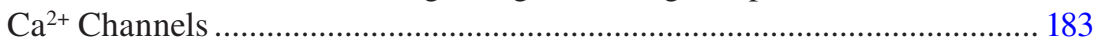

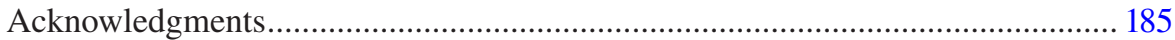

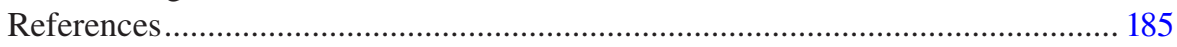

\subsection{INTRODUCTION}

Features of $\mathrm{Ca}^{2+}$ signals including the amplitude, duration, frequency and location are encoded by various physiological stimuli. These features of the signals are decoded by cells to selectively activate smooth muscle functions that include contraction and proliferation [1-3]. Central, therefore, to an appreciation of how smooth muscle is controlled is an understanding of the regulation of $\mathrm{Ca}^{2+}$. In smooth muscle, $\mathrm{Ca}^{2+}$ signals arise from two major sources. The first is the extracellular space from which $\mathrm{Ca}^{2+}$ enters the cell via channels such as voltage-dependent $\mathrm{Ca}^{2+}$ channels, store-operated $\mathrm{Ca}^{2+}$ (SOC) channels and various members of the transient receptor potential channel family. The second major $\mathrm{Ca}^{2+}$ source is the internal $\mathrm{Ca}^{2+}$ store (sarcoplasmic reticulum; SR) [4-6]. The SR accumulates $\mathrm{Ca}^{2+}$ using sarco/endoplasmic reticulum $\mathrm{Ca}^{2+}$-ATPases (SERCA) and $\mathrm{Ca}^{2+}$ is released from the SR via the ligand-gated channel/receptor complexes, the $\mathrm{IP}_{3}$ receptor $\left(\mathrm{IP}_{3} \mathrm{R}\right)$ and ryanodine receptor $(\mathrm{RyR})$. Release of $\mathrm{Ca}^{2+}$ via $\mathrm{IP}_{3} \mathrm{R}$ is activated by 
$\mathrm{IP}_{3}$ generated in response to many $\mathrm{G}$-protein or tyrosine kinase-linked receptor activators including drugs [7,8]. RyR may be activated pharmacologically (e.g., caffeine), by $\mathrm{Ca}^{2+}$ influx from outside the cell in the process of $\mathrm{Ca}^{2+}$-induced $\mathrm{Ca}^{2+}$ release (CICR), or when the stores $\mathrm{Ca}^{2+}$ content exceeds normal physiological values, that is in store overload [2,9-12].

Activation of either $\mathrm{Ca}^{2+}$ influx or $\mathrm{Ca}^{2+}$ release results in an increase of the cytoplasmic $\mathrm{Ca}^{2+}$ concentration $\left(\left[\mathrm{Ca}^{2+}\right]_{\mathrm{c}}\right.$ ) from the resting value of $\sim 100 \mathrm{nM}$ to $\sim 1 \mu \mathrm{M}$ for many seconds throughout the cell, and transiently (e.g., $100 \mathrm{~ms}$ ) to much higher values (e.g., $50 \mu \mathrm{M})$ in small parts of the cytoplasm close to sites of influx or $\mathrm{Ca}^{2+}$ release. These local $\mathrm{Ca}^{2+}$ signals begin with the opening of one or a few channels, allowing a large flux of the ion into the cytoplasm. Influx to the cytoplasm via voltage-dependent $\mathrm{Ca}^{2+}$ channels occurs at rates of $\sim 0.6$ million $\mathrm{Ca}^{2+}$ ions per second per channel (0.2 pA current). The influx generates a significant local concentration gradient near the channel in which $\left[\mathrm{Ca}^{2+}\right]$ declines from $\sim 10 \mu \mathrm{M}$ to $\sim 100 \mathrm{nM}$ over a few hundred nanometers from the plasma membrane [2,13-17]. Voltage-dependent $\mathrm{Ca}^{2+}$ channel open time is brief $(\sim 1 \mathrm{~ms})$ and the gradient dissipates rapidly with rates of change in the subplasma membrane space on the order of $\sim 5000 \mu \mathrm{M} \mathrm{s}^{-1}$ [2] as compared to a much slower rate of $\sim 0.5 \mu \mathrm{M} \mathrm{s}^{-1}$ in the bulk cytoplasm [2] after a global $\left[\mathrm{Ca}^{2+}\right]$ rise $[18,19]$. The large difference in rate of decline in the subplasma membrane space and bulk cytoplasm arise because local changes are driven mostly by buffering and diffusion while the slower rate of decline in bulk cytoplasm is determined by pumps. High local $\left[\mathrm{Ca}^{2+}\right]$ and the rapid rates of change near channels may target processes with rapid $\mathrm{Ca}^{2+}$ binding kinetics to selectively activate particular functions [20-23]. The high local $\left[\mathrm{Ca}^{2+}\right]$ signals arising from influx also, in turn, may activate $\mathrm{IP}_{3} \mathrm{R}$ or RyR to amplify the local signals or propagate through the cell as global signals with slower but more widespread effects [24-30]. The transition of signals from those involving single to multiple channels and from local to global $\mathrm{Ca}^{2+}$ increases creates a multitude of signals with various locations, magnitudes and time courses [31-34] so that various cellular biological responses may be selectively activated.

It is acknowledged that a major way that $\mathrm{Ca}^{2+}$ signaling specifically targets particular biological processes is by increases in concentration of the ion being selectively localized to certain regions of the cell (Figure 9.1) [36,37]. In native smooth muscle cells, mitochondria contribute to the localization of $\mathrm{Ca}^{2+}$ signals and to the modulation of the amplitude of $\mathrm{Ca}^{2+}$ signals [38-42]. Mitochondria regulate these local signals by the organelles' ability to take up and release the ion. $\mathrm{Ca}^{2+}$ uptake occurs through the mitochondrial $\mathrm{Ca}^{2+}$ uniporter while efflux is mediated by the mitochondrial $\mathrm{Na}^{+} / \mathrm{Ca}^{2+}$ exchanger. Mitochondrial $\mathrm{Ca}^{2+}$ uptake and efflux may regulate cytoplasmic $\mathrm{Ca}^{2+}$ concentrations both directly and indirectly. Direct regulation occurs by alteration of bulk $\mathrm{Ca}^{2+}$ levels (Figures 9.2 and 9.3) [18,40,44-47]. Indirect regulation occurs as a result of mitochondrial influence on the activity of SR or plasma membrane $\mathrm{Ca}^{2+}$ channels. This chapter describes how the structure and positioning of mitochondria contribute to the control of $\mathrm{Ca}^{2+}$ signaling, including a previously unrecognized ability of the position of the organelles to increase local $\mathrm{Ca}^{2+}$ entry via voltage-dependent $\mathrm{Ca}^{2+}$ channels. 
(a)
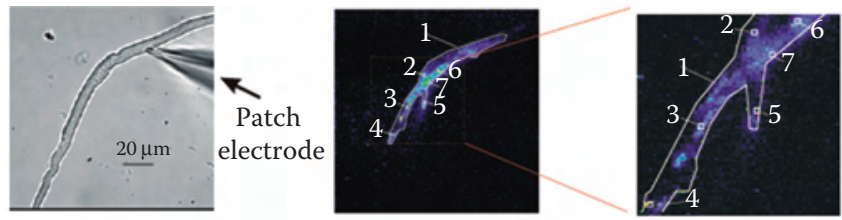

(b)

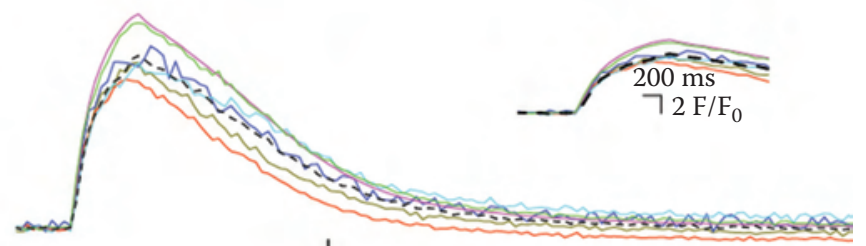

$2 \mathrm{~F} / \mathrm{F}_{0}$

)

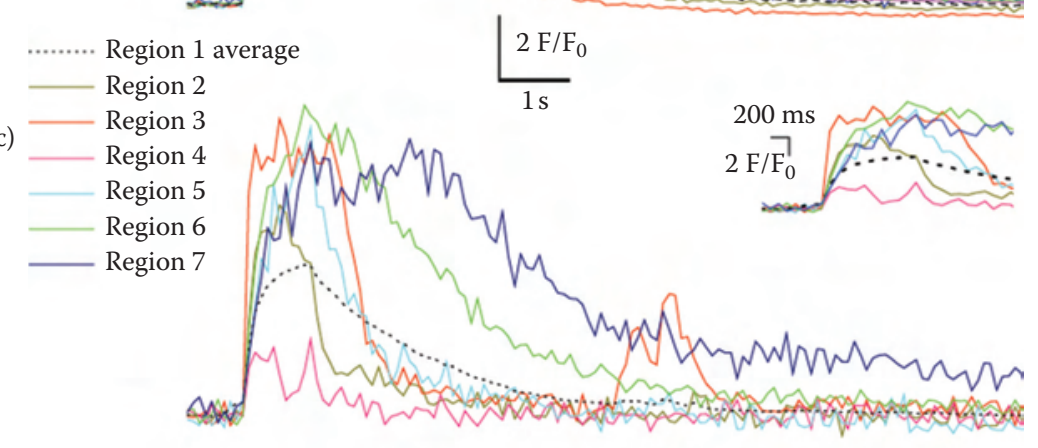

Region 1 average

Region 2

(c)

(d)

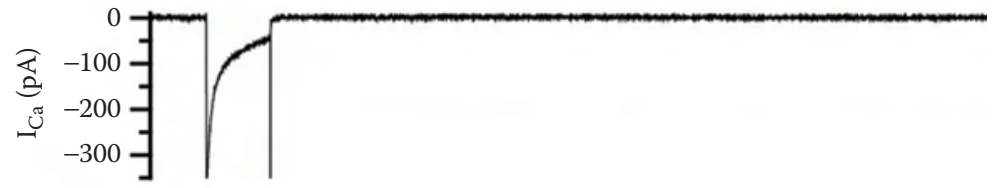

(e)

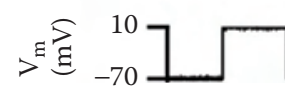

FIGURE 9.1 Simultaneous wide-field epi-fluorescence and total internal reflection fluorescence (TIRF) $\left[\mathrm{Ca}^{2+}\right]$ measurements in a voltage-clamped smooth muscle. Depolarization $\left(-70\right.$ to $+10 \mathrm{mV}$; e), activated a voltage-dependent $\mathrm{Ca}^{2+}$ current $\left(\mathrm{I}_{\mathrm{Ca}}\right.$; d) to evoke a rise in $\left[\mathrm{Ca}^{2+}\right]$ in both the subplasma membrane space (c) and bulk cytoplasm (b). The rise in $\left[\mathrm{Ca}^{2+}\right]$ that occurred in the subplasma membrane space (measured by TIRF) (c) was more rapid in onset than that seen in the bulk cytoplasm (measured by wide-field epi-fluorescence) (b). Changes in the fluorescence ratio with time (b and c) are each derived from precisely the same $2 \times 2$-pixel boxes (regions 1-6 in (a), middle and right (expanded) panel; drawn at a $3 \times 3$-pixel size to facilitate visualization) and from a larger region encompassing the entire TIRF region (region 7). Significantly, while the cytosolic $\left[\mathrm{Ca}^{2+}\right]$ increase that occurred in the bulk cytoplasm (b) was approximately uniform and simultaneous throughout the cell, those in subplasma membrane space (c) had a wide range of amplitudes and various time courses. Insets in (b) and (c) show the rising phase of the transients on an expanded time base. Black dotted lines are the average responses. (Reproduced from McCarron, J.G. et al., J. Gen. Physiol., 133, 439-457, 2009. With permission.) 


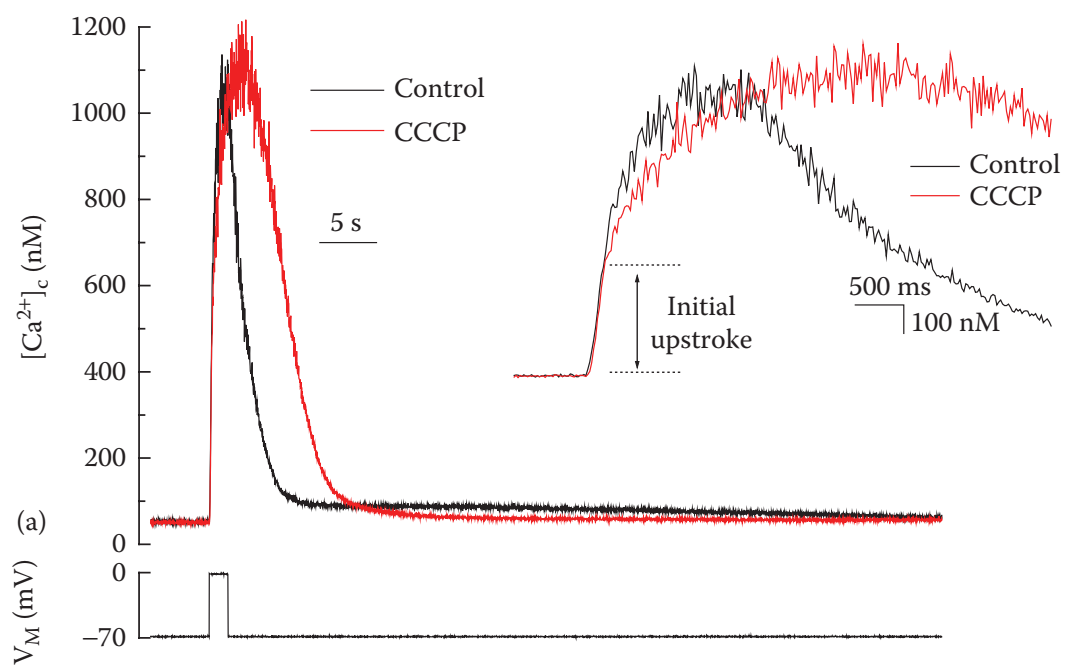

(b)

FIGURE 9.2 Preventing mitochondrial $\mathrm{Ca}^{2+}$ uptake does not alter the initial upstroke or peak cytosolic $\left[\mathrm{Ca}^{2+}\right]$ after depolarization-evoked $\mathrm{Ca}^{2+}$ entry. Depolarization ( -70 to $0 \mathrm{mV}$; b) of a voltage-clamped single smooth muscle cell activated a voltage-dependent $\mathrm{Ca}^{2+}$ current (not shown) and an increased cytosolic $\left[\mathrm{Ca}^{2+}\right]$ (a). After carbonyl cyanide $m$-chlorophenyl hydrazone (CCCP; $5 \mu \mathrm{M}$; transients in red lines) neither the initial rate of cytosolic $\left[\mathrm{Ca}^{2+}\right]$ rise (see inset) or peak cytosolic $\left[\mathrm{Ca}^{2+}\right]$ achieved were significantly altered. The insets show the transients on an expanded time base. Cytosolic $\left[\mathrm{Ca}^{2+}\right]$ was measured at a frequency of $50 \mathrm{~Hz}$ using the membrane-impermeable fura-2 (potassium salt, $50 \mu \mathrm{M}$ ) introduced into the cell from the patch pipette. (Reproduced from McCarron, J.G. et al., Pflugers Arch., 464, 51-62, 2012. With permission.)

\subsection{ROLE OF MITOCHONDRIA IN Ca ${ }^{2+}$ SIGNALING}

Mitochondria are major hubs for cellular signaling. In smooth muscle, mitochondria control contractility, proliferation, and growth through regulation of cytoplasmic $\mathrm{Ca}^{2+}$ concentrations. A critical feature of mitochondria's ability to control $\mathrm{Ca}^{2+}$ signaling is the position and structure of the organelles within cells. Understanding of the precise relationship between $\mathrm{Ca}^{2+}$ signaling and mitochondrial structure and position in living, fully-differentiated, (native) cells is preliminary, which may be due to the uncertainty in mitochondrial structure in these cells. Most studies describing mitochondrial structure are derived from cells maintained in culture conditions. Yet, the structure and arrangement of mitochondria in cultured cells differ substantially from the organelles in fully differentiated smooth muscle cells [48-51]. In cultured cells the position of mitochondria contributes significantly to regulation of cytoplasmic $\mathrm{Ca}^{2+}$ signals and to the control of mitochondrial $\mathrm{Ca}^{2+}$ concentration $\left(\left[\mathrm{Ca}^{2+}\right]_{\mathrm{m}}\right)$. For example, SOC increased the $\left[\mathrm{Ca}^{2+}\right]_{\mathrm{m}}$ in the cultured endothelial cell culture line ECV304, suggesting the organelles accumulate this $\mathrm{Ca}^{2+}$ influx. In ECV304 cells, $14 \%$ of mitochondria are positioned close to the plasma membrane, a position that will facilitate $\mathrm{Ca}^{2+}$ uptake. Less than $4 \%$ of mitochondria are close to the internal 


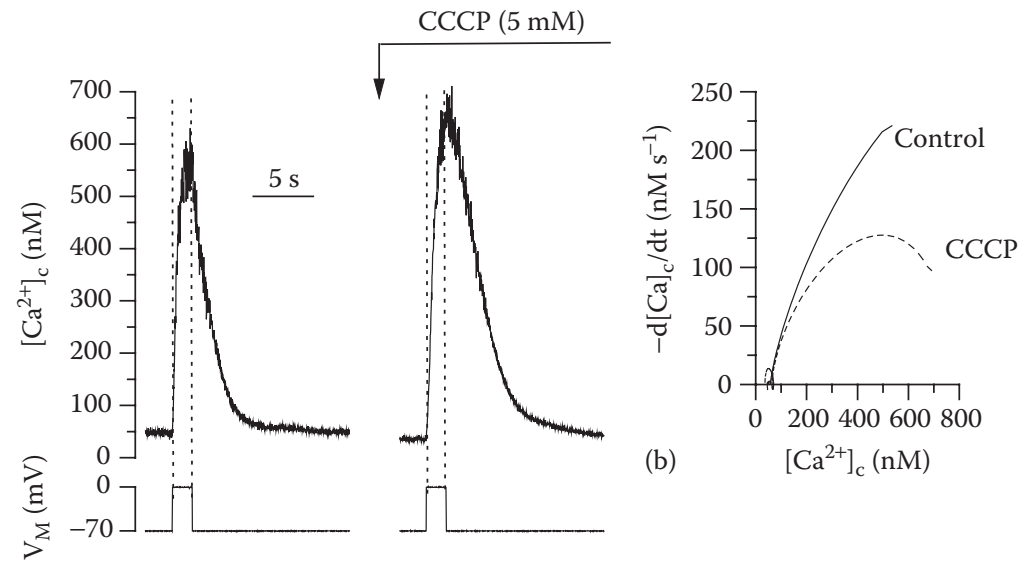

(a)

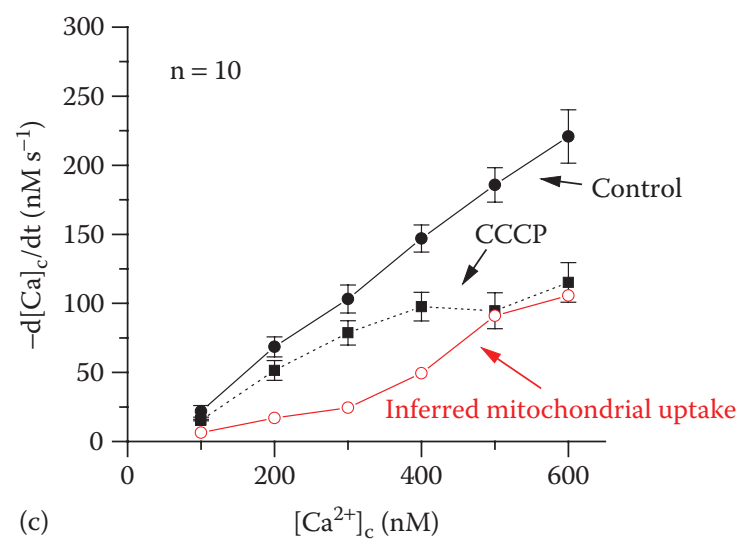

FIGURE 9.3 Mitochondria contribute to cytosolic $\left[\mathrm{Ca}^{2+}\right]$ decline following voltage-dependent $\mathrm{Ca}^{2+}$ entry in smooth muscle. (a) Depolarization $(-70$ to $0 \mathrm{mV}$ ) activated a voltage-dependent $\mathrm{Ca}^{2+}$ current (not shown) and increased cytosolic $\left[\mathrm{Ca}^{2+}\right]$. Carbonyl cyanide $m$-chlorophenyl hydrazone (CCCP; $5 \mu \mathrm{M})$ slowed the rate of decline of cytosolic $\left[\mathrm{Ca}^{2+}\right]$ on repolarization compared with control. (b) The rate of decline of the two transients (a) is shown in (b). The derivative (b) was obtained from high-order polynomial fits to the declining phase of the transient and shows a significant slowing when mitochondria were prevented from accumulating $\mathrm{Ca}^{2+}$. (c) A summary of the rates of decline for ten cells in the presence and absence of CCCP. The inferred mitochondrial contribution to the decline of cytosolic $\left[\mathrm{Ca}^{2+}\right]$ (red line) was obtained by subtracting control rates from those seen in $\mathrm{CCCP}$ and shows that mitochondrial $\mathrm{Ca}^{2+}$ uptake occurred above $200 \mathrm{nM}\left[\mathrm{Ca}^{2+}\right]_{\mathrm{c}}$. (Reproduced from McCarron, J.G. et al., J. Physiol., 516: 149-161, 1999. With permission.)

store and store release of $\mathrm{Ca}^{2+}$ did not increase $\left[\mathrm{Ca}^{2+}\right]_{\mathrm{m}}$. Conversely in HeLa cells, where $65 \%$ of mitochondria are close to the internal store and $<6 \%$ are in close proximity to the plasma membrane, store release of $\mathrm{Ca}^{2+}$ caused a much greater increase in $\left[\mathrm{Ca}^{2+}\right]_{\mathrm{m}}$ than did SOC [52]. These observations suggest mitochondrial position is critical in determining the organelles' uptake of $\mathrm{Ca}^{2+}$. In turn, the position of the mitochondria regulates SOC $[53,54]$. Forced relocation of mitochondria away from 
the cell periphery and towards the nucleus (by overexpressing dynamitin, a protein involved in mitochondrial movement) decreased SOC following store depletion in HeLa cells [55]. These results point to the position of mitochondria as being critical in regulation of $\mathrm{Ca}^{2+}$ signaling.

In native fully-differentiated cell types the distribution of mitochondria may also regulate $\mathrm{Ca}^{2+}$ signaling. For example, in fully-differentiated cardiac myocytes or neurons, mitochondria appear to be located particularly close to sites of initiation of $\mathrm{Ca}^{2+}$ signals from voltage-dependent $\mathrm{Ca}^{2+}$ channels on the plasma membrane [56]. At these sites mitochondria contribute to the clearance of $\mathrm{Ca}^{2+}$ from the mouth of the channel, limiting $\mathrm{Ca}^{2+}$-dependent inactivation and thus prolonging channel open time [57,58] and facilitating $\mathrm{Ca}^{2+}$ entry. In smooth muscle, however, mitochondrial $\mathrm{Ca}^{2+}$ uptake does not appear to alter the kinetics of voltage-dependent $\mathrm{Ca}^{2+}$ entry (Figure 9.2). This observation suggests the gating of voltage-dependent $\mathrm{Ca}^{2+}$ channels is not altered by mitochondria. Notwithstanding the absence of a direct effect on voltage-dependent $\mathrm{Ca}^{2+}$ channels, mitochondria may modulate $\mathrm{Ca}^{2+}$ rises arising from voltage-dependent $\mathrm{Ca}^{2+}$ entry in smooth muscle by modulating $\mathrm{Ca}^{2+}$-dependent feedback processes operative on other ion channels. Mitochondria appear to increase clearance of bulk cytoplasmic $\mathrm{Ca}^{2+}$ concentrations, and as a result decrease the activity of $\mathrm{Ca}^{2+}$-activated chloride channels $\left(\mathrm{Cl}_{\mathrm{Ca}}\right)$ [59] and increase the activity of $\mathrm{Ca}^{2+}$-activated $\mathrm{K}^{+}$channels $\left(\mathrm{K}_{\mathrm{Ca}}\right)$ [60]. Pharmacological inhibition of the ability of mitochondria to remove $\mathrm{Ca}^{2+}$ from the cytoplasm prolonged the activity of $\mathrm{Cl}_{\mathrm{Ca}}$ in portal vein smooth muscle cells [59] and inhibited $\mathrm{K}_{\mathrm{Ca}}$ currents in cerebral artery smooth muscle [60]. Modulation of $\mathrm{Cl}_{\mathrm{Ca}}$ or $\mathrm{K}_{\mathrm{Ca}}$ will alter the membrane potential to then regulate $\mathrm{Ca}^{2+}$ influx via voltage-dependent $\mathrm{Ca}^{2+}$ channels as a result.

By taking up $\mathrm{Ca}^{2+}$, mitochondria modulate the time course and amplitude of $\mathrm{Ca}^{2+}$ signals to shape the resulting message [1]. For example, we have shown that the $\mathrm{Ca}^{2+}$ transient arising from activation of voltage-dependent $\mathrm{Ca}^{2+}$ channels has an accelerated rate of decline as a consequence of mitochondrial $\mathrm{Ca}^{2+}$ uptake; when uptake is inhibited, the rate of $\mathrm{Ca}^{2+}$ decline is substantially slowed (Figures 9.2 and 9.3). In the example shown in Figure 9.3, mitochondria modulate $\mathrm{Ca}^{2+}$ signals over the cytosolic $\left[\mathrm{Ca}^{2+}\right]$ range $600 \mathrm{nM}-200 \mathrm{nM}$, which demonstrates that mitochondria have a high affinity for $\mathrm{Ca}^{2+}$ (in the sub-micromolar range; Figure 9.3). Mitochondrial $\mathrm{Ca}^{2+}$ uptake does not alter the rate, or extent, of $\mathrm{Ca}^{2+}$ influx via voltage-dependent $\mathrm{Ca}^{2+}$ channels [1] (the likely reasons for this are discussed later on). Some studies have shown that increased mitochondrial reactive oxygen species (ROS) production can alter voltage-dependent $\mathrm{Ca}^{2+}$ influx [61], however, this is likely to be due to ROS-dependent alterations in channel open time or conductance, rather than altered mitochondrial $\mathrm{Ca}^{2+}$ uptake during voltage-dependent $\mathrm{Ca}^{2+}$ influx.

Mitochondria also have the capacity to modulate $\mathrm{Ca}^{2+}$ signals that are $\sim 2$ orders of magnitude larger than the global $\mathrm{Ca}^{2+}$ transient arising from voltage-dependent $\mathrm{Ca}^{2+}$ channels and in the tens of micromolar range [62]. One notable example in smooth muscle is mitochondrial regulation of $\mathrm{IP}_{3}$-mediated $\mathrm{Ca}^{2+}$ signals that arise from the activity of a single $\mathrm{IP}_{3} \mathrm{R}$ cluster $\left(\mathrm{Ca}^{2+}\right.$ puffs; Figure 9.4). When mitochondria are prevented from taking up $\mathrm{Ca}^{2+}$ (using uncouplers, complex I inhibitors or uniporter inhibitors), the upstroke of $\mathrm{Ca}^{2+}$ puffs is inhibited [42] (Figure 9.4). The duration of the upstroke of a puff is determined by the open time of $\mathrm{IP}_{3} \mathrm{R}$ in the cluster. 
(a)
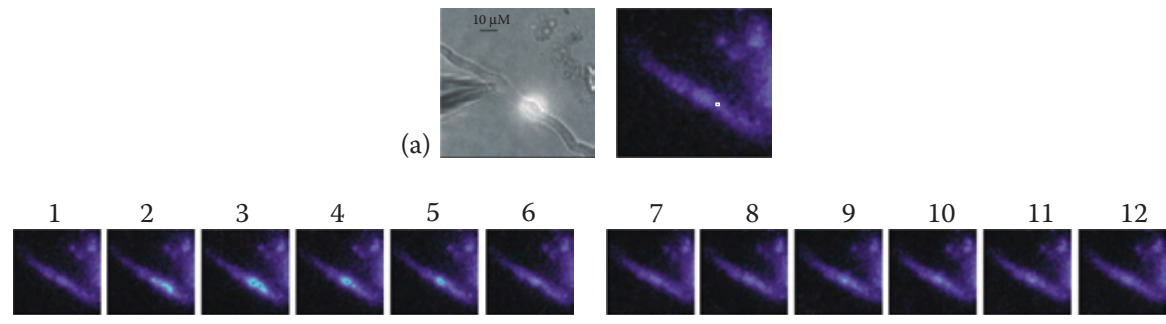

(b)

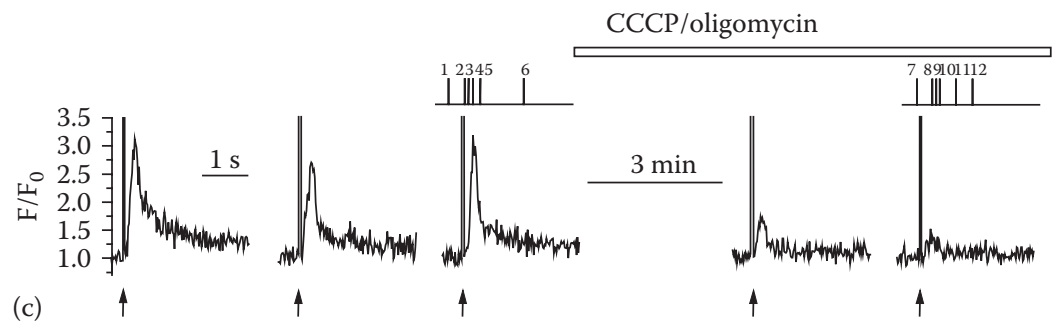

FIGURE 9.4 Preventing mitochondrial $\mathrm{Ca}^{2+}$ uptake by depolarizing $\Delta \Psi m$ with CCCP/ oligomycin inhibits $\mathrm{Ca}^{2+}$ release from $\mathrm{IP}_{3} \mathrm{R}$ clusters $\left(\mathrm{Ca}^{2+}\right.$ puffs). At $-70 \mathrm{mV}$, locally photolyzed caged InsP $\mathrm{P}_{3}(25 \mu \mathrm{M})(\uparrow, \mathrm{C})$ in a $\sim 20 \mu \mathrm{m}$ diameter region (a; bright spot in left-hand panel, see also whole cell electrode, left side) evoked $\mathrm{Ca}^{2+}$ puffs in an EGTA $(300 \mu \mathrm{M})$ buffered smooth muscle cell $(\mathrm{b}, \mathrm{c})$. Note: There are two individual $\mathrm{Ca}^{2+}$ puff sites in response to photorelease of $\mathrm{InsP}_{3}$; one site releases $\mathrm{Ca}^{2+}$ just before the other site. Flash photolysis of $\mathrm{InsP}_{3}$ every $\sim 60$ s generated approximately comparable cytosolic $\left[\mathrm{Ca}^{2+}\right]$ increases. (c) Superfusion of carbonyl cyanide $m$-chlorophenyl hydrazone (CCCP) and oligomycin $(1 \mu \mathrm{M}$ and $6 \mu \mathrm{M}$, respectively) while continuing to photolyze $\mathrm{InsP}_{3}$ at $\sim 60$ intervals, decreased the amplitude of $\mathrm{InsP}_{3}$ mediated $\mathrm{Ca}^{2+}$ puffs (b, c). The cytosolic $\left[\mathrm{Ca}^{2+}\right]$ images (b) are derived from the time points indicated by the corresponding numbers in (c). Cytosolic $\left[\mathrm{Ca}^{2+}\right]_{\mathrm{c}}$ changes in (b) are expressed by color; dark blue low and light blue high cytosolic $\left[\mathrm{Ca}^{2+}\right]$. Measurements were made from a single $3 \times 3$-pixel box (a; right hand panel, white square). The large increase in fluorescence at time 0 is the flash artefact triggering photolysis of caged $\mathrm{IP}_{3}$. (Reproduced from Olson, M.L. et al., J. Biol. Chem., 285, 2040-2050, 2010. With permission.)

The observation [42] that mitochondria modulates the puff upstroke suggests that the organelle's uptake is fast enough to modulate $\mathrm{Ca}^{2+}$ concentration near $\mathrm{IP}_{3} \mathrm{R}$ clusters during the channels open time, requiring mitochondria to have a very low affinity for $\mathrm{Ca}^{2+}\left(\mathrm{Ca}^{2+}\right.$ puffs $\left.>10 \mu \mathrm{M}\right)$ and to be positioned close to the channel.

Electron microscopy studies of porcine tracheal smooth muscle cells suggest that $99 \%$ of mitochondria were within $30 \mathrm{~nm}$ of SR and $48 \%$ of the mitochondrial outer membrane was within $30 \mathrm{~nm}$ with the SR [63] with some mitochondria fully ensheathed by SR $[63,64]$. Given the proximity between sites of $\mathrm{Ca}^{2+}$ release and mitochondria, the question arises as to whether or not there is a direct intermolecular link between the two structures. While there are no high-resolution studies of this link in smooth muscle, electron tomographs [65] and transmission electron micrographs [66] in other cells show tethers that connect the endoplasmic reticulum (ER) to the mitochondrial outer membrane that may be significant in $\mathrm{Ca}^{2+}$ signaling. Indeed, immunocytochemical studies show that those regions of the ER in close 
proximity to mitochondria are also enriched with $\mathrm{IP}_{3} \mathrm{R}$ to create hotspots for the transfer of $\mathrm{Ca}^{2+}$ from the ER to mitochondria [62]. Several molecular candidates for the tethers have been identified in cell types other than smooth muscle cells. The $\mathrm{IP}_{3} \mathrm{R}$ itself has been shown to be tethered to the mitochondrial voltage-dependent anion channel (VDAC) via the chaperone glucose-regulated protein 75 (GRP75), an interaction that promotes mitochondrial accumulation of $\mathrm{Ca}^{2+}$ released by $\mathrm{IP}_{3} \mathrm{R}$ [67]. Interestingly, both in vitro treatment of epithelial cells with high glucose and longterm hyperglycemia in a mouse model of diabetes reduced GRP75 levels, reducing ER-mitochondrial contact sites [68]. The protein mitofusin-2 is located on both mitochondrial and ER membranes and is proposed to form homodimeric tethers between the organelles [69] that contribute to $\mathrm{Ca}^{2+}$ signaling. Disrupting linkages between the SR and mitochondria by gene silencing of mitofusin-2 decreased mitochondrial $\mathrm{Ca}^{2+}$ uptake during $\mathrm{IP}_{3}$-mediated $\left[\mathrm{Ca}^{2+}\right]_{\mathrm{c}}$ rises $[65,69]$. The multifunctional sorting protein PACS-2, which is localized to the ER and may play a role in apoptotic pathway initiation, has also been proposed to be important for maintaining close apposition of ER and mitochondria in the A7 astrocyte cell line [70]. siRNA silencing of PACS-2 caused mitochondrial fragmentation and separation from the ER, altering $\mathrm{Ca}^{2+}$ signaling by increasing $\mathrm{IP}_{3}$-mediated $\mathrm{Ca}^{2+}$ release [70]. The sigma-1 receptor, a protein involved in cell stress responses and present on the ER at regions in close contact with mitochondria, may also couple the membranes of the two organelles [71]. The sigma-1 receptor may form a complex with another chaperone protein (BiP) to stabilize $\mathrm{IP}_{3} \mathrm{R}$ at regions of ER-mitochondrial proximity. Depletion of ER $\mathrm{Ca}^{2+}$ dissociates the sigma-1 receptor from BiP, leading to prolonged $\mathrm{Ca}^{2+}$ signaling into mitochondria via $\mathrm{IP}_{3} \mathrm{Rs}$ [71].

The question arises: how can mitochondria-by removing $\mathrm{Ca}^{2+}$ from the cytoplasm (i.e., lowering $\left[\mathrm{Ca}^{2+}\right]$ ) - generate a larger cytoplasmic $\left[\mathrm{Ca}^{2+}\right]$ rise? $\mathrm{IP}_{3} \mathrm{R}$ are regulated by $\mathrm{Ca}^{2+}$-dependent positive and negative feedback mechanisms [72,73]. By removing $\mathrm{Ca}^{2+}$, mitochondria may limit a negative feedback inhibition of $\mathrm{Ca}^{2+}$ on $\mathrm{IP}_{3} \mathrm{R}$ [42]. There are at least two types of $\mathrm{Ca}^{2+}$-dependent negative feedback mechanisms that may deactivate smooth muscle $\mathrm{IP}_{3} \mathrm{R}$. In the first, a $\mathrm{Ca}^{2+}$-dependent deactivation of $\mathrm{IP}_{3} \mathrm{R}$ occurs at cytosolic $\left[\mathrm{Ca}^{2+}\right.$ exceeding $\sim 300 \mathrm{nM}$ [73]. The onset is rapid and the deactivation is persistent and lasts for $\sim 5 \mathrm{~s}$ after the cytosolic [ $\left.\mathrm{Ca}^{2+}\right]$ increase has ended [74]. Another form of $\mathrm{Ca}^{2+}$-dependent deactivation of $\mathrm{IP}_{3} \mathrm{R}$, once initiated by an increased cytosolic $\left[\mathrm{Ca}^{2+}\right]$, persisted for tens of seconds after cytosolic $\left[\mathrm{Ca}^{2+}\right]$ had regained resting values, that is, $\mathrm{IP}_{3} \mathrm{R}$ became, at least partially, refractory $[30,75]$. Each of these processes would persistently restrict $\mathrm{Ca}^{2+}$ release via $\mathrm{IP}_{3} \mathrm{R}$. Mitochondrial $\mathrm{Ca}^{2+}$ uptake, by buffering the $\mathrm{Ca}^{2+}$ rise at $\mathrm{IP}_{3} \mathrm{R}$, presumably prevented a persistent deactivation of $\mathrm{IP}_{3} \mathrm{R}$ that would otherwise limit the overall release of $\mathrm{Ca}^{2+}[30,75]$.

The control that mitochondria exert on $\mathrm{Ca}^{2+}$ puffs enables the organelle to exert particularly dramatic effects on the global $\mathrm{Ca}^{2+}$ events such as $\mathrm{Ca}^{2+}$ waves and oscillations. When mitochondria are prevented from taking up $\mathrm{Ca}^{2+}$, waves and oscillations halt $[42,45]$, that is, modulation of the time course of a $\mathrm{Ca}^{2+}$ rise by the organelle determines whether or not some $\mathrm{Ca}^{2+}$ signals occur at all. The position and structure of the organelles, together with nano-architectural features of SR-mitochondria junctions, is critical in determining precisely how mitochondria regulate local and global $\mathrm{Ca}^{2+}$ signals. 


\subsection{MITOCHONDRIA STRUCTURE IN NATIVE CELLS}

The precise structure and position of mitochondria have been studied most extensively in cultured smooth muscle cells because of the relative ease that the organelles can be visualized in these cells. The thin axial depth of cultured cells and ability to transfect the cells to express unique, mitochondrially-targeted fluorophores result in exceptional signal to noise for imaging mitochondrial structure. In cultured cells, mitochondria exist in a wide range of sizes and shapes (Figure 9.5) and the organelle may change rapidly from solitary ovoid shapes to extensive branched networks and

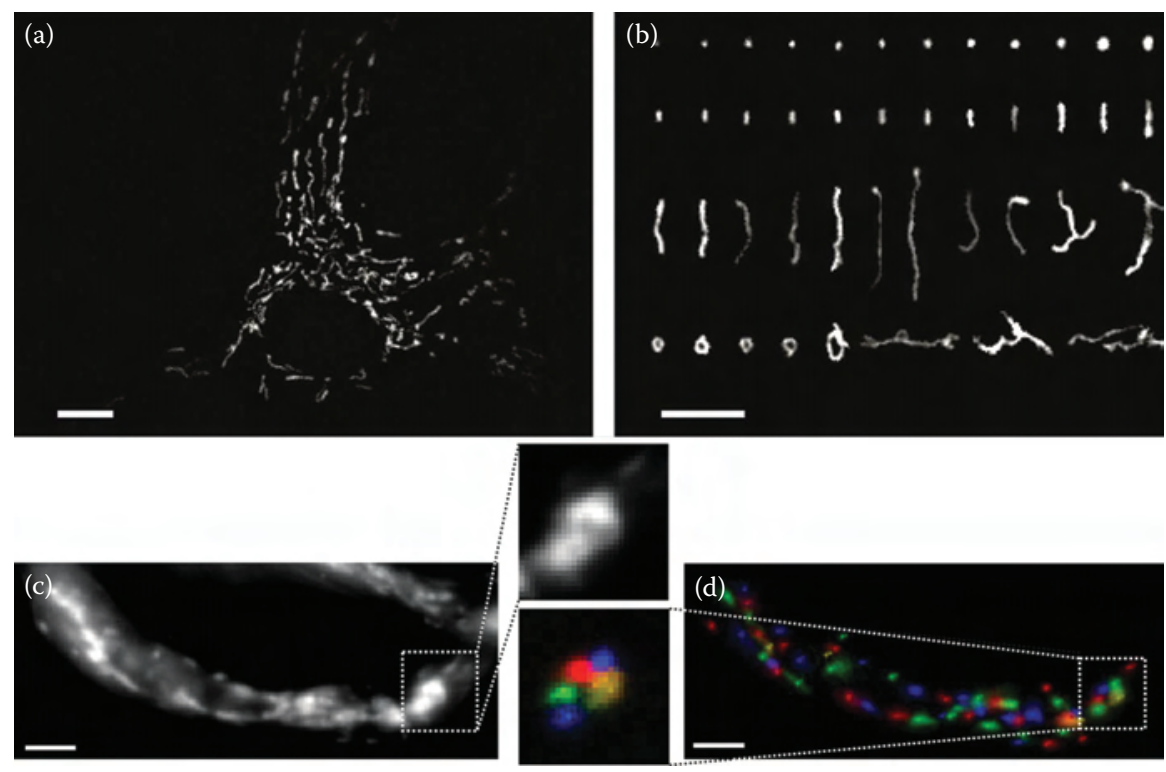

FIGURE 9.5 Mitochondrial structures in cultured and fully-differentiated smooth muscle cells. (a) A cultured single vascular smooth muscle cell showing the arrangement of mitochondria. The organelle is scattered through the cytoplasm and is arranged in various orientations. Mitochondria were labeled with the mitotracker green. (b) Example mitochondria showing the diverse phenotypes which include small spheres, swollen spheres, straight rods, twisted rods, branched rods, and loops. (a and b reproduced from McCarron, J. et al., J. Vasc. Res., 5, 357-371, 2013. With permission.) (c) A native fully-differentiated smooth muscle cell from a cerebral resistance artery showing the arrangement of mitochondria as revealed by the fluorophore tetramethylrhodamine, ethyl ester (TMRE). The organelle is distributed throughout the cytoplasm and appears to be mainly organized parallel to the long axis of the cell. However, the significant axial depth of the cells (when compared to cultured smooth muscle) and multiple overlapping fluorescence point sources result in an optically-confused image with structures that are hard to interpret (d) FaLM permits the size, shape, and position of mitochondria to determined and shows the organelles comprise mainly spheres and short rods. The inset between $\mathrm{c}$ and $\mathrm{d}$ shows the same example region of the cell before and after application of FaLM. (c and d modified from Chalmers, S. et al., Nat. Sci. Rep., 30, 2000-2013, 2015. With permission.) Scale bars $=10 \mu \mathrm{m}$. 
even single continuous mitochondrial structure throughout the cell $[62,76,77]$. This almost continuous re-shaping creates a diversity of structures (Figure 9.5), presumably each with different physiological roles although the precise functions are not yet fully understood $[51,78]$. On the other hand, mitochondria within fully-differentiated live smooth muscle cells are difficult to visualize because of the significant axial cell depth. This depth results in multiple confused overlapping fluorescence point sources at different distances through the cell derived from various mitochondria. The overlapping fluorescence is difficult to interpret and may be single large organelles or multiple small mitochondria. Exclusive fluorophore targeting is also more difficult in native cells than in cultured cells. Whether or not the arrangements of mitochondria seen in cultured cells occur in fully-differentiated cells is uncertain.

Live cell imaging is required to appreciate the precise relationship between position and structure of mitochondria and the control of $\mathrm{Ca}^{2+}$ signaling in fully-differentiated cells. Confocal or other optical sectioning imaging methods do not provide sufficient resolution to determine detailed structure of the organelle in fully-differentiated cells. Detailed insights into the structure of individual mitochondria at fixed points in time have been provided by electron microscopy [EM; 79]. However, EM cannot easily resolve the entire cellular mitochondrial complement or provide information on dynamic changes or functional connectivity and is not compatible with $\mathrm{Ca}^{2+}$ imaging. EM [80] and super-resolution techniques [81-89] do not unambiguously reveal the extent of the electrically-continuous inner mitochondrial membrane and are less suited to simultaneously studying $\mathrm{Ca}^{2+}$ signaling in live cells, nor do they currently have the imaging speed frequently required.

We recently developed a technique to determine the structure of individual, electrically-discrete mitochondria in live, fully-differentiated cells using conventional fluorescence imaging. Our approach is rapid and quantifies the shape, size and location of mitochondria even when the organelles are densely clustered. The approach measures transient changes in the membrane potential that are unique to each mitochondrion to determine their individual shapes. Changes in membrane potential $(\Delta \Psi \mathrm{m})$ arise from transient openings of the mitochondrial permeability transition pore [mPTP; 90,91] and can be visualized using a rapidly-repartitioning cationic fluorophore such as TMRE, as flickers of fluorescence [92,93]. These flickers demarcate individual, electrically-discrete mitochondria [92,94]. Drawing inspiration from PALM/BaLM super-resolution techniques [81,82], we used these flicker events to extract structural information of each organelle, facilitating a more detailed analysis of the live-cell fluorescence images. These mitochondrial flickers differ from the correlation of photo-activation, bleaching, or blinking in PALM/BaLM because the flickering objects are not single molecule emitters with a well-defined point-spread function but extended organelles of unknown shape. Nonetheless, the size, shape, and position of the mitochondria can be rapidly determined to the conventional resolution limit from a pixel-by-pixel spatio-temporal covariance of the derived flickering fluorescence signals in an approach that we call Flicker-assisted Localization Microscopy (FaLM) [49,50].

Using FaLM, we found that mitochondria in fully-differentiated resistance artery smooth muscle cells were distributed through the cytoplasm as solitary, spherical-, or short rod-shaped entities (Figure 9.5) [50]. We found mitochondria had a median 
area of $0.46 \mu \mathrm{m}^{2}$, a median length of $0.9 \mu \mathrm{m}$, and a median length:width ratio of 1.5. We also found the median density of mitochondria in resistance artery smooth muscle cells was 0.125 mitochondria per $\mu \mathrm{m}^{2}$ and that mitochondria occupied $7.0 \%$ of the cell volume. Each mitochondrion had 2-5 immediate neighbors with $\sim 2 \mu \mathrm{m}$ between the organelle centers. The mean center distance of a mitochondria from the plasma membrane was $\sim 2 \mu \mathrm{m}$ [49]. Given a width of mitochondria of $0.6 \mu \mathrm{m}$, then, the edge distance of the organelle from the plasma membrane is $1.4 \mu \mathrm{m}$. The opening of a single voltage-dependent $\mathrm{Ca}^{2+}$ channel ( $0.2 \mathrm{pA}$ current, mean open-time $1 \mathrm{~ms}$ ) generates a high local $\left[\mathrm{Ca}^{2+}\right]$ that decreases steeply with distance from the plasma membrane as the ion diffuses into an increasing hemispheric volume. At a distance of $1.4 \mu \mathrm{m}$ from the plasma membrane the $\left[\mathrm{Ca}^{2+}\right]$ arising from the opening of the channel is only $\sim 5 \mathrm{nM}$ above resting values (assuming a buffer power of 100). It is unlikely that this microdomain of $\mathrm{Ca}^{2+}$ will be significantly altered by mitochondria. Clearly, the local rise in $\left[\mathrm{Ca}^{2+}\right]$, and potential contribution of mitochondria, will increase if more than one channel opens or if mitochondria position is different as occurs in some other cell types.

\subsection{MITOCHONDRIAL POSITION AND SIGNALING VIA VOLTAGE-DEPENDENT $\mathrm{Ca}^{2+}$ CHANNELS}

Mitochondria situated immediately at sites of $\mathrm{Ca}^{2+}$ influx or release into the cytoplasm may form part of subcellular $\mathrm{Ca}^{2+}$-signaling microdomains and have a privileged access to $\mathrm{Ca}^{2+}$ from these sites $[38,42,44,62,95]$. While, in smooth muscle, $\mathrm{Ca}^{2+}$ influx via voltage-dependent $\mathrm{Ca}^{2+}$ channels appears not to be tightly controlled at a local level by mitochondria (Figure 9.2) [44,45], nonetheless, the sites of mitochondria near the plasma membrane are associated with larger $\mathrm{Ca}^{2+}$ signals than elsewhere in the plasma membrane (Figure 9.6). Thus, a single voltage-clamped cerebral resistance artery smooth muscle cell, activated with a depolarizing pulse (-70 to $0 \mathrm{mV}$ ) responded with voltage-dependent $\mathrm{Ca}^{2+}$ entry and a rise in cytoplasmic $\mathrm{Ca}^{2+}$ concentration (Figure 9.6). In this same cell, mitochondrial position was determined (Figure 9.6) using the $\Delta \Psi \mathrm{m}$-sensitive dye TMRE (see Section 9.3). Interestingly, the amplitude of the local rise in cytoplasmic $\mathrm{Ca}^{2+}$ concentration was largest at these sites close to mitochondria (Figure 9.6).

After the depolarization ended, at precisely the same sites, there was a substantial undershoot in the cytoplasmic $\mathrm{Ca}^{2+}$ concentration when compared to regions away from mitochondria (Figure 9.6). These results suggest that mitochondria may regulate (increase) voltage-dependent $\mathrm{Ca}^{2+}$ entry and aid the removal of $\mathrm{Ca}^{2+}$ from the cytoplasm positioned close to the plasma membrane.

The upstroke of the voltage-dependent $\mathrm{Ca}^{2+}$ transient is unaltered when mitochondria are prevented from taking up $\mathrm{Ca}^{2+}$ (Figure 9.2), which suggests that mitochondria are not regulating channel gating. The question arises as to how do mitochondria regulate voltage-dependent $\mathrm{Ca}^{2+}$ entry? One possibility is that mitochondria are not involved in the short-term regulation of $\mathrm{Ca}^{2+}$ entry but rather in the longer-term level of either expression or distribution of the voltage-dependent $\mathrm{Ca}^{2+}$ channel. $\mathrm{IP}_{3}$ mediated $\mathrm{Ca}^{2+}$ release has been shown to induce mitochondrial-ROS generation, 


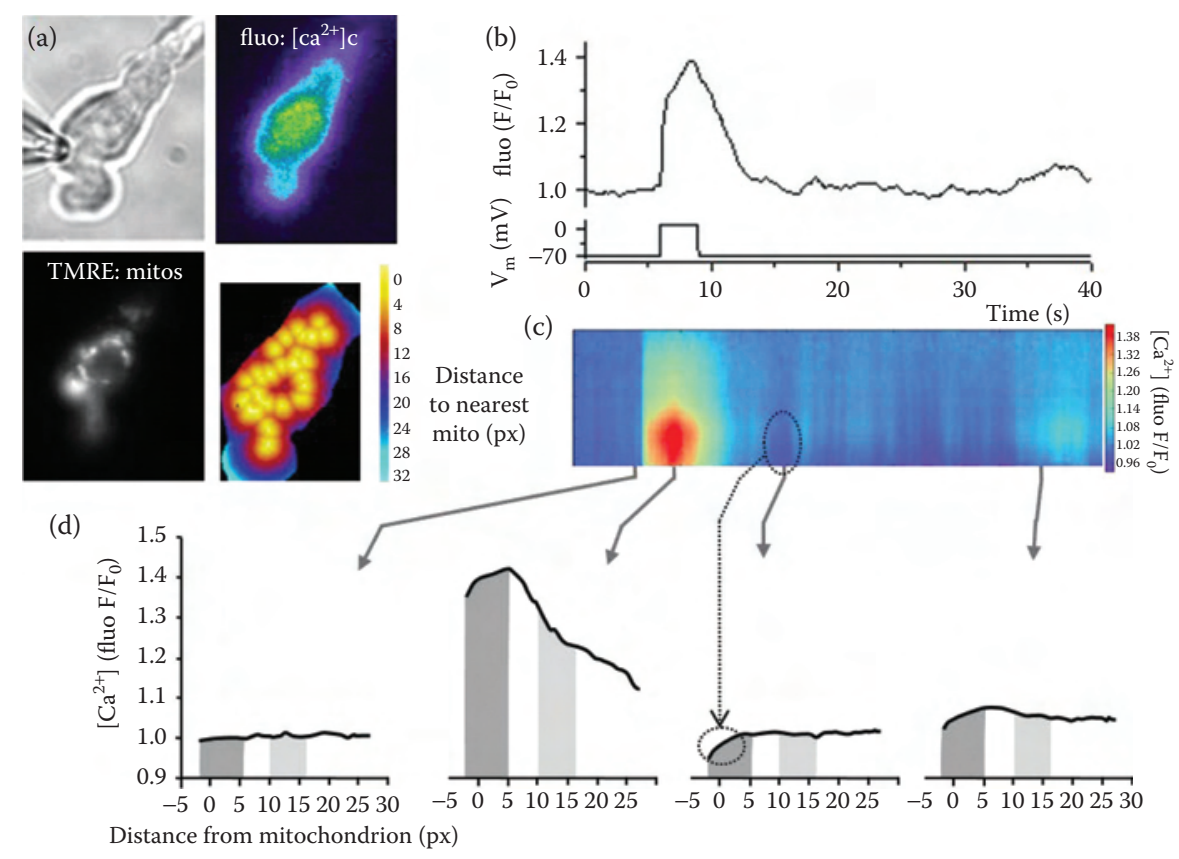

FIGURE 9.6 Mitochondrial position and the magnitude of $\left[\mathrm{Ca}^{2+}\right]$ changes arising from voltage-dependent $\mathrm{Ca}^{2+}$ entry. Depolarization ( -70 to $0 \mathrm{mV}$; b), of a single voltage-clamped smooth muscle cell (a-upper left panel) activated a voltage-dependent $\mathrm{Ca}^{2+}$ current (not shown) and rise in $\left[\mathrm{Ca}^{2+}\right](\mathrm{a}$ - upper right panel, $\mathrm{b}$, and $\mathrm{c})$. The rise in $\left[\mathrm{Ca}^{2+}\right]$ declined after the depolarization ended. Mitochondrial position was determined at the same time by labeling the organelles with TMRE (a-lower left panel). The magnitude of the rise in $\left[\mathrm{Ca}^{2+}\right]$ throughout the cell (b and c) was compared on a pixel-by-pixel basis to the center of mass of each nearest mitochondrion (a-lower left and right panels). The rise in $\left[\mathrm{Ca}^{2+}\right]$ was largest close to a mitochondrion (c and d). In (c) the $\mathrm{Ca}^{2+}$ signal in each pixel is plotted as a function of time (x-axis; same scale as b) and distance to the nearest mitochondrion (left y-axis). The magnitude of the $\left[\mathrm{Ca}^{2+}\right]$ is colored-red high, blue low. After the depolarization had ended, (b) there was an undershoot in $\left[\mathrm{Ca}^{2+}\right]$ at those regions closest to a mitochondrion (c; shown as darker blue regions and indicated by the dotted lines). (d) Plots the pixel $\left[\mathrm{Ca}^{2+}\right]$ as a function of distance from the nearest mitochondrion ( 0 on the $\mathrm{x}$ axis is the mitochondrial position) at 4 time points indicated by the arrows from (c). The shaded regions highlight the differences in $\mathrm{Ca}^{2+}$ signals close (darker gray) and further (lighter gray) from a mitochondrion. Those regions that are closest to mitochondria experience the highest $\left[\mathrm{Ca}^{2+}\right]$ concentration after a depolarization and the greatest undershoot (indicated by the dotted lines) as $\left[\mathrm{Ca}^{2+}\right]$ returns to resting values.

activate the transcription factor NF-kappaB, and stimulate voltage-dependent $\mathrm{Ca}^{2+}$ channel transcription [96]. It is tempting to speculate that mitochondria may therefore control voltage-dependent $\mathrm{Ca}^{2+}$ channel expression following persistent entry via voltage-dependent $\mathrm{Ca}^{2+}$ channels. It is also tempting to speculate that the regional changes in $\mathrm{Ca}^{2+}$ (Figure 9.1) arising from voltage-dependent $\mathrm{Ca}^{2+}$ channel entry arise from mitochondrial control of the distribution of the channel. The localized decreases in $\mathrm{Ca}^{2+}$ near mitochondria also offer support to the proposed control mechanisms operating to regulate and maintain $\mathrm{IP}_{3}$-mediated $\mathrm{Ca}^{2+}$ release (Figure 9.4). 


\section{ACKNOWLEDGMENTS}

This work was funded by the Wellcome Trust (092292/Z/10/Z; 202924/Z/16/Z) and the British Heart Foundation (PG/16/54/32230; PG16/82/32439), whose support is gratefully acknowledged. CW is supported by a Sir Henry Wellcome Postdoctoral Research Fellowship (204682/Z/16/Z).

\section{REFERENCES}

1. Chalmers, S, Olson, ML, MacMillan, D, Rainbow, RD, McCarron, JG. Ion channels in smooth muscle: Regulation by the sarcoplasmic reticulum and mitochondria. Cell Calcium 42: 447-466, 2007.

2. McCarron, JG, Chalmers, S, Bradley, KN, Macmillan, D, Muir, TC. Ca ${ }^{2+}$ microdomains in smooth muscle. Cell Calcium 40: 461-493, 2006.

3. Sanders, KM. Invited review: Mechanisms of calcium handling in smooth muscles. J Appl Physiol 91: 1438-1449, 2001.

4. Macmillan, D, McCarron, JG. The phospholipase C inhibitor U-73122 inhibits $\mathrm{Ca}(2+)$ release from the intracellular sarcoplasmic reticulum $\mathrm{Ca}(2+)$ store by inhibiting $\mathrm{Ca}(2+)$ pumps in smooth muscle. Br J Pharmacol 160: 1295-1301, 2010.

5. McCarron, JG, Olson, ML. A single luminally continuous sarcoplasmic reticulum with apparently separate $\mathrm{Ca}^{2+}$ stores in smooth muscle. J Biol Chem 283: 7206-7218, 2008.

6. Rainbow, RD, Macmillan, D, McCarron, JG. The sarcoplasmic reticulum $\mathrm{Ca}^{2+}$ store arrangement in vascular smooth muscle. Cell Calcium 46: 313-322, 2009.

7. Berridge, MJ. Inositol trisphosphate and calcium signalling mechanisms. Biochim Biophys Acta 1793: 933-940, 2009.

8. Lemmon, MA, Schlessinger, J. Cell signaling by receptor tyrosine kinases. Cell 141: 1117-1134, 2010.

9. Burdyga, T, Wray, S. Action potential refractory period in ureter smooth muscle is set by Ca sparks and BK channels. Nature 436: 559-562, 2005.

10. McCarron, JG, Craig, JW, Bradley, KN, Muir, TC. Agonist-induced phasic and tonic responses in smooth muscle are mediated by $\mathrm{InsP}_{3}$. J Cell Sci 115: 2207-2218, 2002.

11. Nelson, MT, Cheng, H, Rubart, M, Santana, LF, Bonev, AD, Knot, HJ, Lederer, WJ. Relaxation of arterial smooth muscle by calcium sparks. Science 270: 633-637, 1995.

12. ZhuGe, R, Tuft, RA, Fogarty, KE, Bellve, K, Fay, FS, Walsh, JV, Jr. The influence of sarcoplasmic reticulum $\mathrm{Ca}^{2+}$ concentration on $\mathrm{Ca}^{2+}$ sparks and spontaneous transient outward currents in single smooth muscle cells. J Gen Physiol 113: 215-228, 1999.

13. Aharon, S, Bercovier, M, Parnas, H. Parallel computation enables precise description of $\mathrm{Ca}^{2+}$ distribution in nerve terminals. Bull Math Biol 58: 1075-1097, 1996.

14. Llinas, R, Sugimori, M, Silver, RB. Microdomains of high calcium concentration in a presynaptic terminal. Science 256: 677-679, 1992.

15. Marsault, R, Murgia, M, Pozzan, T, Rizzuto, R. Domains of high $\mathrm{Ca}^{2+}$ beneath the plasma membrane of living A7r5 cells. Embo J 16: 1575-1581, 1997.

16. Naraghi, M, Neher, E. Linearized buffered $\mathrm{Ca}^{2+}$ diffusion in microdomains and its implications for calculation of $\left[\mathrm{Ca}^{2+}\right]$ at the mouth of a calcium channel. $J$ Neurosci 17 : 6961-6973, 1997.

17. Schneggenburger, R, Neher, E. Intracellular calcium dependence of transmitter release rates at a fast central synapse. Nature 406: 889-893, 2000.

18. Kamishima, T, McCarron, JG. $\mathrm{Ca}^{2+}$ removal mechanisms in rat cerebral resistance size arteries. Biophys J 75: 1767-1773, 1998. 
19. McGeown, JG, McCarron, JG, Drummond, RM, Fay, FS. Calcium-calmodulindependent mechanisms accelerate calcium decay in gastric myocytes from Bufo marinus. J Physiol 506 (Pt 1): 95-107, 1998.

20. Bao, R, Lifshitz, LM, Tuft, RA, Bellve, K, Fogarty, KE, ZhuGe, R. A close association of RyRs with highly dense clusters of $\mathrm{Ca}^{2+}$-activated $\mathrm{Cl}^{-}$channels underlies the activation of STICs by $\mathrm{Ca}^{2+}$ sparks in mouse airway smooth muscle. J Gen Physiol 132: 145-160, 2008.

21. Kargacin, GJ. Responses of $\mathrm{Ca}^{2+}$-binding proteins to localized, transient changes in intracellular $\left[\mathrm{Ca}^{2+}\right]$. J Theor Biol 221: 245-258, 2003.

22. Macrez, N, Mironneau, J. Local $\mathrm{Ca}^{2+}$ signals in cellular signalling. Curr Mol Med 4: 263-275, 2004.

23. Zhuge, R, Bao, R, Fogarty, KE, Lifshitz, LM. $\mathrm{Ca}^{2+}$ sparks act as potent regulators of excitation-contraction coupling in airway smooth muscle. J Biol Chem 285: 2203-2210, 2009.

24. Bai, Y, Edelmann, M, Sanderson, MJ. The contribution of inositol 1,4,5-trisphosphate and ryanodine receptors to agonist-induced $\mathrm{Ca}^{2+}$ signaling of airway smooth muscle cells. Am J Physiol Lung Cell Mol Physiol 297: L347-L361, 2009.

25. Balemba, OB, Heppner, TJ, Bonev, AD, Nelson, MT, Mawe, GM. Calcium waves in intact guinea pig gallbladder smooth muscle cells. Am J Physiol Gastrointest Liver Physiol 291: G717-G727, 2006.

26. Boittin, FX, Macrez, N, Halet, G, Mironneau, J. Norepinephrine-induced $\mathrm{Ca}^{2+}$ waves depend on $\mathrm{InsP}_{3}$ and ryanodine receptor activation in vascular myocytes. Am J Physiol 277: C139-C151, 1999.

27. Gordienko, DV, Harhun, MI, Kustov, MV, Pucovsky, V, Bolton, TB. Sub-plasmalemmal $\left[\mathrm{Ca}^{2+}\right]_{\mathrm{i}}$ upstroke in myocytes of the guinea-pig small intestine evoked by muscarinic stimulation: $\mathrm{IP}_{3} \mathrm{R}$-mediated $\mathrm{Ca}^{2+}$ release induced by voltage-gated $\mathrm{Ca}^{2+}$ entry. Cell Calcium 43: 122-141, 2008.

28. Jaggar, JH, Nelson, MT. Differential regulation of $\mathrm{Ca}^{2+}$ sparks and $\mathrm{Ca}^{2+}$ waves by UTP in rat cerebral artery smooth muscle cells. Am J Physiol Cell Physiol 279: C1528C1539, 2000.

29. McCarron, JG, Chalmers, S, MacMillan, D, Olson, ML. Agonist-evoked $\mathrm{Ca}^{2+}$ wave progression requires $\mathrm{Ca}^{2+}$ and $\mathrm{IP}_{3}$. J Cell Physiol 244: 334-344, 2010.

30. McCarron, JG, MacMillan, D, Bradley, KN, Chalmers, S, Muir, TC. Origin and mechanisms of $\mathrm{Ca}^{2+}$ waves in smooth muscle as revealed by localized photolysis of caged inositol 1,4,5-trisphosphate. J Biol Chem 279: 8417-8427, 2004.

31. Bai, Y, Sanderson, MJ. Airway smooth muscle relaxation results from a reduction in the frequency of $\mathrm{Ca}^{2+}$ oscillations induced by a cAMP-mediated inhibition of the $\mathrm{IP}_{3}$ receptor. Respir Res 7: 34, 2006.

32. Berridge, MJ, Lipp, P, Bootman, MD. The versatility and universality of calcium signalling. Nat Rev Mol Cell Biol 1: 11-21, 2000.

33. Bootman, MD, Berridge, MJ. The elemental principles of calcium signaling. Cell 83: 675-678, 1995.

34. Marchant, JS, Parker, I. Role of elementary $\mathrm{Ca}^{2+}$ puffs in generating repetitive $\mathrm{Ca}^{2+}$ oscillations. Embo J 20: 65-76, 2001.

35. McCarron, JG, Olson, ML, Currie, S, Wright, AJ, Anderson, KI, Girkin, JM. Elevations of intracellular calcium reflect normal voltage-dependent behavior, and not constitutive activity, of voltage-dependent calcium channels in gastrointestinal and vascular smooth muscle. J Gen Physiol 133: 439-457, 2009.

36. Parekh, AB. Store-operated $\mathrm{Ca}^{2+}$ entry: Dynamic interplay between endoplasmic reticulum, mitochondria and plasma membrane. J Physiol 547: 333-348, 2003.

37. Rizzuto, R, Brini, M, Murgia, M, Pozzan, T. Microdomains with high $\mathrm{Ca}^{2+}$ close to $\mathrm{IP}_{3^{-}}$ sensitive channels that are sensed by neighboring mitochondria. Science 262: 744-747, 1993. 
38. Arnaudeau, S, Kelley, WL, Walsh, JV, Jr., Demaurex, N. Mitochondria recycle $\mathrm{Ca}^{2+}$ to the endoplasmic reticulum and prevent the depletion of neighboring endoplasmic reticulum regions. J Biol Chem 276: 29430-29439, 2001.

39. Drummond, RM, Fay, FS. Mitochondria contribute to $\mathrm{Ca}^{2+}$ removal in smooth muscle cells. Pflugers Arch 431: 473-482, 1996.

40. Drummond, RM, Mix, TC, Tuft, RA, Walsh, JV, Jr., Fay, FS. Mitochondrial $\mathrm{Ca}^{2+}$ homeostasis during $\mathrm{Ca}^{2+}$ influx and $\mathrm{Ca}^{2+}$ release in gastric myocytes from Bufo marinus. J Physiol 522: 375-390, 2000.

41. Drummond, RM, Tuft, RA. Release of $\mathrm{Ca}^{2+}$ from the sarcoplasmic reticulum increases mitochondrial $\left[\mathrm{Ca}^{2+}\right]$ in rat pulmonary artery smooth muscle cells. $J$ Physiol $516(\mathrm{Pt} 1)$ : 139-147, 1999.

42. Olson, ML, Chalmers, S, McCarron, JG. Mitochondrial $\mathrm{Ca}^{2+}$ uptake increases $\mathrm{Ca}^{2+}$ release from inositol 1,4,5-trisphosphate receptor clusters in smooth muscle cells. J Biol Chem 285: 2040-2050, 2010.

43. McCarron, JG, Olson, ML, Chalmers, S. Mitochondrial regulation of cytosolic $\mathrm{Ca}^{2+}$ signals in smooth muscle. Pflugers Arch 464: 51-62, 2012.

44. McCarron, JG, Muir, TC. Mitochondrial regulation of the cytosolic $\mathrm{Ca}^{2+}$ concentration and the $\mathrm{InsP}_{3}$-sensitive $\mathrm{Ca}^{2+}$ store in guinea-pig colonic smooth muscle. $J$ Physiol 516: 149-161, 1999.

45. Chalmers, S, McCarron, JG. The mitochondrial membrane potential and $\mathrm{Ca}^{2+}$ oscillations in smooth muscle. J Cell Sci 121: 75-85, 2008.

46. Kamishima, T, Davies, NW, Standen, NB. Mechanisms that regulate $\left[\mathrm{Ca}^{2+}\right]_{\mathrm{i}}$ following depolarization in rat systemic arterial smooth muscle cells. J Physiol 522: 285-295, 2000.

47. Kamishima, T, McCarron, JG. Regulation of the cytosolic $\mathrm{Ca}^{2+}$ concentration by $\mathrm{Ca}^{2+}$ stores in single smooth muscle cells from rat cerebral arteries. J Physiol 501: 497-508, 1997.

48. Chalmers, S, Saunter, C, Wilson, C, Coats, P, Girkin, JM, McCarron, JG. Mitochondrial motility and vascular smooth muscle proliferation. Arterioscler Thromb Vasc Biol 32: 3000-3011, 2012.

49. Chalmers, S, Saunter, CD, Girkin, JM, McCarron, JG. Age decreases mitochondrial motility and increases mitochondrial size in vascular smooth muscle. $J$ Physiol 594: 4283-4295, 2016.

50. Chalmers, S, Saunter, CD, Girkin, JM, McCarron, JG. Flicker-assisted localization microscopy reveals altered mitochondrial architecture in hypertension. Nat Sci Rep 30: 2000-2013, 2015.

51. McCarron, J, Wilson, C, Sandison, ME, Olson, ML, Girkin, JM, Saunter, C, Chalmers, S. From structure to function: Mitochondrial morphology, motion and shaping in vascular smooth muscle. J Vasc Res 5: 357-371, 2013.

52. Lawrie, AM, Rizzuto, R, Pozzan, T, Simpson, AW. A role for calcium influx in the regulation of mitochondrial calcium in endothelial cells. J Biol Chem 271: 10753, 1996.

53. Hoth, M, Button, DC, Lewis, RS. Mitochondrial control of calcium-channel gating: A mechanism for sustained signaling and transcriptional activation in T lymphocytes. Proc Natl Acad Sci USA 97: 10607-10612, 2000.

54. Hoth, M, Fanger, CM, Lewis, RS. Mitochondrial regulation of store-operated calcium signaling in T lymphocytes. J Cell Biol 137: 633-648, 1997.

55. Varadi, A, Cirulli, V, Rutter, GA. Mitochondrial localization as a determinant of capacitative $\mathrm{Ca}^{2+}$ entry in HeLa cells. Cell Calcium 36: 499, 2004.

56. Barstow, KL, Locknar, SA, Merriam, LA, Parsons, RL. The modulation of action potential generation by calcium-induced calcium release is enhanced by mitochondrial inhibitors in mudpuppy parasympathetic neurons. Neuroscience 124: 327, 2004.

57. Hernandez-Guijo, JM, Maneu-Flores, VE, Ruiz-Nuno, A, Villarroya, M, Garcia, AG, Gandia, L. Calcium-dependent inhibition of $\mathrm{L}, \mathrm{N}$, and $\mathrm{P} / \mathrm{Q} \mathrm{Ca}^{2+}$ channels in chromaffin cells: Role of mitochondria. J Neurosci 21: 2553, 2001. 
58. Sanchez, JA, Garcia, MC, Sharma, VK, Young, KC, Matlib, MA, Sheu, SS. Mitochondria regulate inactivation of L-type $\mathrm{Ca}^{2+}$ channels in rat heart. J Physiol 536: 387-396, 2001.

59. Greenwood, IA, Helliwell, RM, Large, WA. Modulation of $\mathrm{Ca}^{2+}$-activated $\mathrm{Cl}^{-}$currents in rabbit portal vein smooth muscle by an inhibitor of mitochondrial $\mathrm{Ca}^{2+}$ uptake. J Physiol 505: 53-64, 1997.

60. Cheranov, SY, Jaggar, JH. Mitochondrial modulation of $\mathrm{Ca}^{2+}$ sparks and transient $\mathrm{KCa}$ currents in smooth muscle cells of rat cerebral arteries. J Physiol 556: 755-771, 2004.

61. Ochi, R, Dhagia, V, Lakhkar, A, Patel, D, Wolin, MS, Gupte, SA. Rotenone-stimulated superoxide release from mitochondrial complex I acutely augments L-type Ca2+ current in A7r5 aortic smooth muscle cells. Am J Physiol Heart Circ Physiol 310: H1118H1128, 2016.

62. Rizzuto, R, Pinton, P, Carrington, W, Fay, FS, Fogarty, KE, Lifshitz, LM, Tuft, RA, Pozzan, T. Close contacts with the endoplasmic reticulum as determinants of mitochondrial $\mathrm{Ca}^{2+}$ responses. Science 280: 1763-1766, 1998.

63. Dai, J, Kuo, KH, Leo, JM, van Breemen, C, Lee, CH. Rearrangement of the close contact between the mitochondria and the sarcoplasmic reticulum in airway smooth muscle. Cell Calcium 37: 333-340, 2005.

64. Nixon, GF, Mignery, GA, Somlyo, AV. Immunogold localization of inositol 1,4,5-trisphosphate receptors and characterization of ultrastructural features of the sarcoplasmic reticulum in phasic and tonic smooth muscle. J Muscle Res Cell Motil 15: 682-700, 1994.

65. Csordas, G, Renken, C, Varnai, P, Walter, L, Weaver, D, Buttle, KF, Balla, T, Mannella, CA, Hajnoczky, G. Structural and functional features and significance of the physical linkage between ER and mitochondria. J Cell Biol 174: 915-921, 2006.

66. Boncompagni, S, Rossi, AE, Micaroni, M, Beznoussenko, GV, Polishchuk, RS, Dirksen, RT, Protasi, F. Mitochondria are linked to calcium stores in striated muscle by developmentally regulated tethering structures. Mol Biol Cell 20: 1058-1067, 2009.

67. Szabadkai, G, Bianchi, K, Varnai, P, De Stefani, D, Wieckowski, MR, Cavagna, D, Nagy, AI, Balla, T, Rizzuto, R. Chaperone-mediated coupling of endoplasmic reticulum and mitochondrial $\mathrm{Ca}^{2+}$ channels. J Cell Biol 175: 901-911, 2006.

68. Ma, JH, Shen, S, Wang, JJ, He, Z, Poon, A, Li J, Qu, J, Zhang, SX. Comparative proteomic analysis of the mitochondria-associated ER membrane (MAM) in a long-term type 2 diabetic rodent model. Sci Rep 7: 2062, 2017.

69. de Brito, OM, Scorrano, L. Mitofusin 2 tethers endoplasmic reticulum to mitochondria. Nature 456: 605-610, 2008.

70. Simmen, T, Aslan, JE, Blagoveshchenskaya, AD, Thomas, L, Wan, L, Xiang, Y, Feliciangeli, SF, Hung, CH, Crump, CM, Thomas, G. PACS-2 controls endoplasmic reticulum-mitochondria communication and Bid-mediated apoptosis. Embo J 24: 717$729,2005$.

71. Hayashi, T, Su, TP. Sigma-1 receptor chaperones at the ER-mitochondrion interface regulate $\mathrm{Ca}^{2+}$ signaling and cell survival. Cell 131: 596-610, 2007.

72. Bezprozvanny, I, Watras, J, Ehrlich, BE. Bell-shaped calcium-response curves of Ins(1,4,5)P3- and calcium-gated channels from endoplasmic reticulum of cerebellum. Nature 351: 751-754, 1991.

73. Iino, M. Biphasic $\mathrm{Ca}^{2+}$ dependence of inositol 1,4,5-trisphosphate-induced $\mathrm{Ca}^{2+}$ release in smooth muscle cells of the guinea pig taenia caeci. J Gen Physiol 95: 1103-1122, 1990.

74. Iino, M, Tsukioka, M. Feedback control of inositol trisphosphate signalling by calcium. Mol Cell Endocrinol 98: 141-146, 1994. 
75. Oancea, E, Meyer, T. Reversible desensitization of inositol trisphosphate-induced calcium release provides a mechanism for repetitive calcium spikes. J Biol Chem 271: 17253-17260, 1996.

76. De Giorgi, F, Lartigue, L, Ichas, F. Electrical coupling and plasticity of the mitochondrial network. Cell Calcium 28: 365-370, 2000.

77. Guillery, O, Malka, F, Frachon, P, Milea, D, Rojo, M, Lombes, A. Modulation of mitochondrial morphology by bioenergetics defects in primary human fibroblasts. Neuromuscul Disord 18: 319-330, 2008.

78. Mitra, K, Wunder, C, Roysam, B, Lin, G, Lippincott-Schwartz, J. A hyperfused mitochondrial state achieved at G1-S regulates cyclin E buildup and entry into $\mathrm{S}$ phase. Proc Natl Acad Sci USA 106: 11960-11965, 2009.

79. Mannella, CA. Structural diversity of mitochondria: Functional implications. Ann N Y Acad Sci 1147: 171-179, 2008.

80. Frey, TG, Mannella, CA. The internal structure of mitochondria. Trends Biochem Sci 25: 319-324, 2000.

81. Betzig, E, Patterson, GH, Sougrat, R, Lindwasser, OW, Olenych, S, Bonifacino, JS, Davidson, MW, Lippincott-Schwartz, J, Hess, HF. Imaging intracellular fluorescent proteins at nanometer resolution. Science 313: 1642-1645, 2006.

82. Burnette, DT, Sengupta, P, Dai, Y, Lippincott-Schwartz, J, Kachar, B. Bleaching/blinking assisted localization microscopy for superresolution imaging using standard fluorescent molecules. Proc Natl Acad Sci USA 108: 21081-21086, 2011.

83. Cox, S, Rosten, E, Monypenny, J, Jovanovic-Talisman, T, Burnette, DT, LippincottSchwartz, J, Jones, GE, Heintzmann, R. Bayesian localization microscopy reveals nanoscale podosome dynamics. Nat Methods 9: 195-200, 2012.

84. Egner, A, Jakobs, S, Hell, SW. Fast 100-nm resolution three-dimensional microscope reveals structural plasticity of mitochondria in live yeast. Proc Natl Acad Sci USA 99: 3370-3375, 2002.

85. Hirvonen, LM, Wicker, K, Mandula, O, Heintzmann, R. Structured illumination microscopy of a living cell. Eur Biophys J 38: 807-812, 2009.

86. Huang, B, Jones, SA, Brandenburg, B, Zhuang, X. Whole-cell 3D STORM reveals interactions between cellular structures with nanometer-scale resolution. Nat Methods 5: 1047-1052, 2008.

87. Jans, DC, Wurm, CA, Riedel, D, Wenzel, D, Stagge, F, Deckers, M, Rehling, P, Jakobs, S. STED super-resolution microscopy reveals an array of MINOS clusters along human mitochondria. Proc Natl Acad Sci USA 110: 8936-8941, 2013.

88. Rosenbloom, AB, Lee, SH, To, M, Lee, A, Shin, JY, Bustamante, C. Optimized two-color super resolution imaging of Drp1 during mitochondrial fission with a slow-switching Dronpa variant. Proc Natl Acad Sci USA 111: 13093-13098, 2014.

89. Shao, L, Kner, P, Rego, EH, Gustafsson, MG. Super-resolution 3D microscopy of live whole cells using structured illumination. Nat Methods 8: 1044-1046, 2011.

90. Giorgio, V, von Stockum, S, Antoniel, M, Fabbro, A, Fogolari, F, Forte, M, Glick GD et al. Dimers of mitochondrial ATP synthase form the permeability transition pore. Proc Natl Acad Sci USA 110: 5887-5892, 2013.

91. Halestrap, AP, Richardson, AP. The mitochondrial permeability transition: A current perspective on its identity and role in ischaemia/reperfusion injury. J Mol Cell Cardiol 78: 129-141, 2015.

92. O’Reilly, CM, Fogarty, KE, Drummond, RM, Tuft, RA, Walsh, JV, Jr. Quantitative analysis of spontaneous mitochondrial depolarizations. Biophys $J$ 85: 3350-3357, 2003. 
93. O'Reilly, CM, Fogarty, KE, Drummond, RM, Tuft, RA, Walsh, JV, Jr. Spontaneous mitochondrial depolarizations are independent of $\mathrm{SR} \mathrm{Ca}^{2+}$ release. Am J Physiol Cell Physiol 286: C1139-C1151, 2004.

94. Duchen, MR, Leyssens, A, Crompton, M. Transient mitochondrial depolarizations reflect focal sarcoplasmic reticular calcium release in single rat cardiomyocytes. J Cell Biol 142: 975-988, 1998.

95. Hajnoczky, G, Csordas, G, Madesh, M, Pacher, P. The machinery of local $\mathrm{Ca}^{2+}$ signalling between sarco-endoplasmic reticulum and mitochondria. J Physiol 529 Pt 1: 69, 2000.

96. Narayanan, D, Xi, Q, Pfeffer, LM, Jaggar, JH. Mitochondria control functional CaV1.2 expression in smooth muscle cells of cerebral arteries. Circ Res 107: 631-641, 2010. 